\title{
First record of the subfamilies Banchinae and Stilbopinae (Hymenoptera: Ichneumonidae) from the Late Eocene Rovno amber (Ukraine)
}

\author{
Первая находка подсемейств Banchinae и Stilbopinae \\ (Hymenoptera: Ichneumonidae) из позднеэоџенового \\ ровенского янтаря (Украина)
}

\begin{abstract}
A.I. Khalaim
А.И. Хацаим

Zoological Institute, Russian Academy of Sciences, St. Petersburg 199034, Russia; Facultad de Ingenieria y Ciencias, Universidad Autónoma de Tamaulipas, Cd. Victoria 87149, Mexico. E-mail: ptera@mail.ru

Зоологический институт Российской академии наук, С.-Петербург 199034, Россия; факультет инженерии и науки, Автономный университет Тамаулипас, Сьюдад Виктория 87149, Мексика.
\end{abstract}

KEY WORDS: Ichneumonidae, Banchinae, Stilbopinae, Rovno amber, taxonomy, Eocene.

КЛЮЧЕВЫЕ СЛОВА: Ichneumonidae, Banchinae, Stilbopinae, ровенский янтарь, систематика, эоцен.

ABSTRACT. A new ichneumonid genus Rovenosa gen.n., with type species Rovenosa rasnitsyni sp.n. (Stilbopinae), and Lissonota perkovskyi sp.n. (Banchinae) are described from the Late Eocene Rovno amber from Ukraine. These taxa are the first records of the subfamilies Banchinae and Stilbopinae in the Rovno amber and the earliest records of the fossil representatives of these subfamilies.

РЕЗЮМЕ. Новый род ихневмонид Rovenosa gen.n. с типовым видом Rovenosa rasnitsyni sp.n. (Stilbopinae) и Lissonota perkovskyi sp.n. (Banchinae) описаны из позднеэоценового ровенского янтаря Украины. Эти таксоны являются первыми находками подсемейств Banchinae и Stilbopinae в ровенском янтаре и самыми ранними находками ископаемых представителей этих подсемейств в целом.

\section{Introduction}

The Rovno amber is deposited in several assemblages situated to the North of Rovno City (Northwest Ukraine). It is chemically identical to the Late Eocene Baltic amber (succinite) of approximately the same age, but differs by the composition of arthropod fauna. In particular, the aquatic and subaquatic arthropods are comparatively rare, while leaf-litter dwellers are very abundant in the Rovno amber. These differences indicate the geographically different origin of the Baltic and Rovno ambers [Perkovsky et al., 2007].

Of more than 50 examined specimens of the Rovno amber Ichneumonidae in the collection of the Institute of Zoology of the National Academy of Sciences of Ukraine (Kiev), two new species belonging to the sub- families Banchinae and Stilbopinae have been discovered.

The new species of Banchinae is a distinctive member of the tribe Atrophini because it has nervellus of the hind wing intercepted in its lower quarter and metasomal tergites 2-4 evenly convex, without lateromedian oblique grooves. On the other hand, this species has the first tergite with complete dorsolateral carinae, the character state unknown among extant genera of Atrophini. This specimen could be placed within the large cosmopolitan genus Lissonota Gravenhorst, 1829, but it differs from all known species of this genus by presence of the dorsolateral carinae of tergite 1 as well as by the distinct notaulus.

Another amber specimen belongs to the small subfamily Stilbopinae by having metanotum with distinct sublateral triangular projection on its hind margin and a completely areolate propodeum with a strong costula. However, ovipositor of this specimen has a distinct dorsal subapical notch. This is unusual for that subfamily and therefore indicates an intermediate position of the species between the subfamilies Stilbopinae and Banchinae.

Stilbopinae comprise only three recent genera with 24 described species, and they utilize members of the primitive lepidopteran family Incurvariidae as hosts [Kasparyan, 1999]. This subfamily is morphologically similar to Banchinae and formerly was considered as a tribe of the latter group [Townes, 1970]. Within Stilbopinae, this species resembles members of the genus Panteles Förster, 1869 by having nervellus of the hind wing intercepted slightly below middle, fore wing with an oblique areolet, and slightly elongate first tergite with dorsomedian carinae developed in its basal 0.4 and almost complete dorsolateral carinae. On the other 
hand, ovipositor of this specimen with a dorsal subapical notch as well as simple tarsal claws suggest that this species does not belong to Panteles because all recent Stilbopinae have ovipositor without the dorsal notch. This information confirms an isolated taxonomic position of the species from the Rovno amber, and this specimen is therefore described below as a new genus and species.

One fossil species of Banchinae, Lampronota disrupta Cockerell, 1921, was described from the Late Eocene Bembridge Marls (Isle of Wight, southern England) [Cockerell, 1921]. Re-examination of the type of this species has revealed that it belonged to another subfamily [Khalaim, 2011, in press]. Certain species of the Banchinae were also described by Brues [1910] from the Florissant beds of Colorado (USA) which are referred now to the uppermost Eocene [Evanoff et al., 2001]. However, the general composition of the ichneumonid fauna indicates its younger age if compared to that of the Baltic and Rovno ambers [Khalaim, 2008, 2011 (in press)]. All other records of the fossil Banchinae belong to Oligocene or Miocene, and most of them require revision (Menier et al., 2004). Fossil members of the subfamily Stilbopinae were unknown up to now.

Types of both new taxa are deposited in the collection of the Institute of Zoology of the National Academy of Sciences of Ukraine (Kiev).

\section{Taxonomic part}

\section{Subfamily Stilbopinae}

\section{Rovenosa gen.n.}

Type species: Rovenosa rasnitsyni sp.n.

DIAGNOSIS. Frons between antennal sockets flat, without crest or carina. Clypeus in lateral view strongly convex. Notaulus well developed. Sternaulus absent. Hind margin of metanotum with sublateral triangular projection. Submetapleural carina slightly raised anteriorly. Propodeum with complete carinae, costula strong. Fore wing with pointed above and oblique areolet (Fig. 1). Hind wing with nervellus intercepted somewhat below middle (Fig. 2). Tarsal claws small, not pectinate. Metasoma cylindrical. Tergite 1 slightly elongate, short and broad, roundly convex in lateral view; dorsomedian carinae developed in basal 0.4 of tergite; dorsolateral carinae almost reaching hind edge of tergite; spiracle situated in basal third of tergite just below dorsolateral carina. Tergites beyond first one short and broad, strongly transverse, without lateromedian oblique grooves. Ovipositor robust, strongly compressed, with apex weakly upcurved, with narrow dorsal subapical notch (Fig. 3); sheath shorter than hind tibia.

TAXONOMIC COMPARISON. The new genus is similar to Panteles Förster in having nervellus of hind wing intercepted slightly below middle, fore wing with oblique areolet, and first tergite slightly elongate, with dorsomedian carinae in its basal 0.4 and more or less complete dorsolateral carinae. Rovenosa gen.n. differs from Panteles by short ovipositor with developed dorsal subapical notch, and by simple tarsal claws.

ETYMOLOGY. Based on the name of locality (Rovno), where the specimen was collected. Gender is feminine.

\section{Rovenosa rasnitsyni sp.n.}

Figs 1-3.

TYPE MATERIAL. Holotype: female, No. K-4152. Well preserved complete ichneumonid wasp.

DESCRIPTION. Female (holotype). Body length about $5.5 \mathrm{~mm}$, fore wing length about $3.75 \mathrm{~mm}$.

Head globose, with large prominent eyes. Temple short, strongly narrowed behind eyes in dorsal view. Labial palpus short, 4-segmented. Maxillary palpus long and slender. Mandible gradually narrowed towards apex, upper tooth somewhat shorter than lower tooth. Malar space much shorter than basal width of mandible (probably about 0.3 times). Clypeus in lateral view strongly convex, distinctly separated from face. Flagellum filiform, its basal and middle segments elongate, subapical segments distinctly transverse.

Notaulus well developed, sharp anteriorly. Upper end of prepectal carina reaching about level of lower corner of pronotum. Hind margin of metanotum with sublateral triangular projection. Pleural carina complete. Propodeum with areola more than 2.5 times as long as broad. Mesoscutum, mesopleuron, metapleuron and probably propodeum densely granulate, without punctation.

Fore wing with areolet oblique and pointed above but without stalk (Fig. 1). Vein $2 m$-cu slightly inclivous, very weakly arcuate. Pterostigma moderately broad, about 3.5 times as long as wide. Metacarp far short apex of fore wing.

Legs slender. Length of hind tibia $1.0 \mathrm{~mm}$, of femur $1.28 \mathrm{~mm}$, and of basitarsus $0.55 \mathrm{~mm}$ respectively. Hind spurs almost straight, moderately long.

Ovipositor sheath about $1.2 \mathrm{~mm}$ long, distinctly shorter than hind tibia.

ETYMOLOGY. Named after the famous palaeontologist and Hymenoptera expert Prof. A.P. Rasnitsyn (Palaeontological Institute of the Russian Academy of Sciences, Moscow, Russia).

\section{Subfamily Banchinae}

\section{Lissonota Gravenhorst, 1829}

This is a very large cosmopolitan genus with about 400 species which is best represented in the Holarctic region [Townes, 1970; Yu et al., 2005]. All host records of the extant species of Lissonota belong to the concealed Lepidoptera larvae living in stems, buds, rolled leaves, tunnels in fruits, and similar locations [Townes, 1970; Townes, Townes, 1978; Gauld et al., 2002]. 

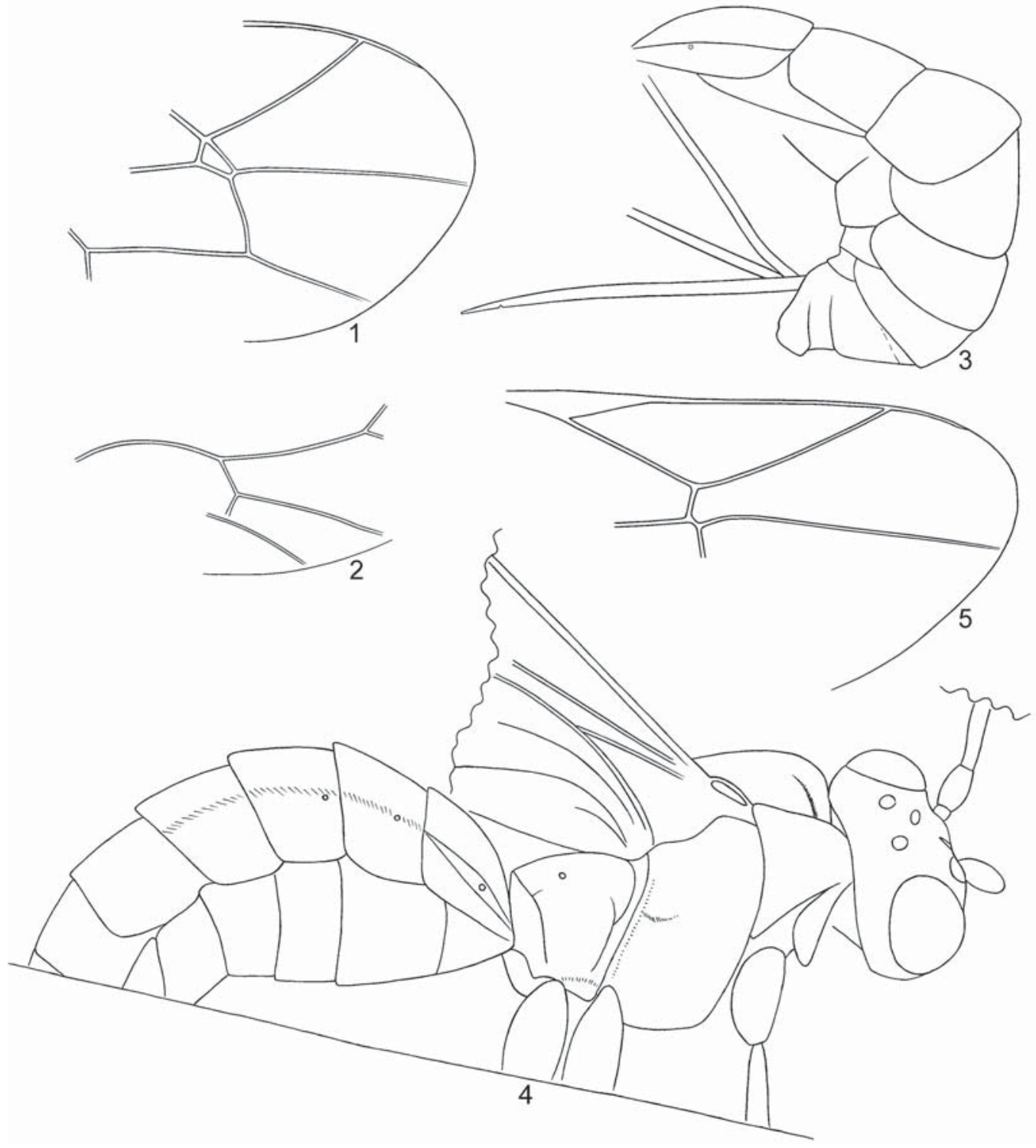

Figs 1-5. Rovenosa rasnitsyni gen. et sp.n. (female, holotype) (1-3) and Lissonota perkovskyi sp.n. (sex unknown, holotype) (4, 5). 1, 5 - apex of fore wing; 2 - fragment of hind wing; 3 - metasoma with ovipositor, lateral view; 4 - body (without wings), lateral view. Рис. 1-5. Rovenosa rasnitsyni gen. et sp.n. (самка, голотип) (1-3) и Lissonota perkovskyi sp.n. (пол неизвестен, голотип) $(4,5) .1$, 5 - вершина переднего крыла; 2 - фрагмент заднего крыла; 3 - метасома с яйцекладом, вид сбоку; 4 - тело (без крыльев), вид сбоку.

\section{Lissonota perkovskyi sp.n.}

Figs 4-5.

TYPE MATERIAL. Holotype: sex unknown, K6611. Moderately well preserved specimen: head with antennae, mesosoma and metasoma (without apex) complete; legs mostly absent, only coxae, one fore leg, femur and tibia of hind leg are present; wings preserved but not completely visible.

DESCRIPTION. Body length about $5.8 \mathrm{~mm}$ (from anterior margin of head to visible apex of metasoma), fore wing length about $4.75 \mathrm{~mm}$.
Head strongly narrowed behind eyes in dorsal view, temple very short. Frons with weak but distinct longitudinal keel between antennal sockets. Distance between lateral ocellus and eye margin 1.6 times diameter of ocellus. Malar space 0.55 times as long as basal width of mandible. Mandible broad and robust (teeth invisible). Clypeus virtually not separated from face, flat, without teeth on its ventral margin, with distinct and sharp punctures, smooth between punctures. Occipital carina complete. Flagellum of antenna with about 31 segments; basal flagellomeres long, middle flagellomeres somewhat elongate, subapical flagellomeres very 
strongly transverse. Face with dense and deep punctures, smooth between punctures.

Mesosoma mostly smooth, more or less densely punctate in some parts; mesopleuron in upper part and propodeum dorsally impunctate. Epomia probably absent. Notaulus anteriorly sharp, rather strongly impressed. Mesoscutum finely and densely punctate. Scutellum, very weakly convex in dorsal view (dorsally almost flat), without tooth. Prepectal carina present. Sternaulus and postpectal carina absent. Hind margin of metanotum without sublateral projection. Submetapleural carina anteriorly expanded into a broad lobe. Metapleural carina almost entirely absent. Propodeum short, with only well developed and broadly arcuate posterior transverse carina.

Fore wing without areolet (Fig. 5). Vein $2 m-c u$ postfurcal, inclivous, straight. Vein $2 r s-m$ long, about 3.0 times as long as abscissa of $M$ between $2 r s-m$ and $2 m-c u$. Pterostigma very narrow. Radial cell narrow, 3.7 times as long as broad. Nervulus distinctly postfurcal, subvertical; distance between nervulus and basal vein 0.3 times length of nervulus. Hind wing with nervellus intercepted in lower 0.24 .

Legs moderately slender. Length of hind femur 1.6 $\mathrm{mm}$. Spurs of hind tibia straight.

Length of first tergite about $1.0 \mathrm{~mm}$, tergite distinctly transverse, weakly and gradually broadened posteriorly, weakly convex dorsally in lateral view, with dorsomedian carinae probably absent and dorsolateral carinae well developed, almost reaching hind edge of tergite; with round spiracle in anterior 0.34 of tergite just below dorsolateral carina. Metasomal tergites dorsally finely and very densely punctate.

TAXONOMIC COMPARISON. The new species belongs to the large and cosmopolitan banchine genus Lissonota and generally looks like extant species of this genus except for the well developed dorsolateral carina of the first tergite (this carina present only basally or totally absent in extant species) and rather strongly impressed notaulus. Lissonota perkovskyi sp.n. is also characterized by the fore wing without areolet (Fig. 5), presence of the longitudinal keel between antennal sockets, strongly transverse subapical flagellomeres, and strongly transverse metasomal tergites (including the first one).

ETYMOLOGY. Named after Dr. E.E. Perkovsky who has made a great contribution to the study of insects of the Rovno amber.

\section{ACKNOWLEDGEMENTS}

I am grateful to Dr. E.E. Perkovsky (Institute of Zoology of the National Academy of Sciences of
Ukraine, Kiev, Ukraine) for loan of the valuable material, and to Dr. D.R. Kasparyan (Zoological Institute of the Russian Academy of Sciences, St. Petersburg, Russia) for his important suggestions during preparation of this paper. This work was supported by grant No. 1004-00265 from the Russian Foundation for Basic Research, and by the Program of the Presidium of the Russian Academy of Sciences "Origin of Biosphere and Evolution of Geobiological System".

\section{References}

Brues C.T. 1910. The parasitic Hymenoptera of the Tertiary of Florissant, Colorado // Bulletin of the Museum of Comparative Zoology at Harvard University. Vol.54. P.1-125.

Cockerell T.D.A. 1921. Fossil Arthropods in the British Museum. - V. Oligocene Hymenoptera from the Isle of Wight // The Annales and Magazine of Natural History. Ser.9. Vol.7. P.125.

Evanoff E., McIntosh W.C., Murphey P.C. 2001. Stratigraphic summary and ${ }^{40} \mathrm{Ar} /{ }^{39} \mathrm{Ar}$ geochronology of the Florissant Formation, Colorado // Proceedings of the Denver Museum of Nature and Science. Ser.4. Vol.1. P.1-16.

Gauld I.D., Sithole R., Gómez J.U., Godoy C. 2002. The Ichneumonidae of Costa Rica. 4 // Memoirs of the American Entomological Institute. Vol.66. P.1-768.

Kasparyan D.R. 1999. [New species of ichneumonid wasps of the subfamily Stilbopinae (Hymenoptera, Ichneumonidae) of the Old World] // Entomologicheskoe obozrenie. Vol.78. No.1. P.163-173 [in Russian].

Khalaim A.I. 2008. Fossil ichneumon wasps (Hymenoptera: Ichneumonidae) from Biamo (Russia), Oligocene // Alavesia. Vol.2. P.101-112.

Khalaim A.I. 2011. Family Ichneumonidae Latreille, 1802 // Antropov A.V., Belokobylskij S.A., Dlussky G.M., Khalaim A.I., Kolyada V.A., Kozlov M.A., Perfilieva K.S., Rasnitsyn A.P. The Hymenopterous Insects (Insecta: Vespida) from the Insect Limestone (Early Oligocene) of the Isle of Wight, UK. Special Papers in Palaeontology, Palaeontological Association, London. In press.

Menier J.J., Nel A., Waller A., De Ploëg G. 2004. A new fossil ichneumon wasp of Paris Basin (France), with a checklist of fossil Ichneumonoidea s.l. (Insecta: Hymenoptera: Ichneumonidae: Metopiinae) // Geologica Acta. Vol.2. No1. P.83-94.

Perkovsky E.E., Rasnitsyn A.P., Vlaskin A.P., Taraschuk M.V. 2007. A comparative analysis of the Baltic and Rovno amber arthropod faunas: representative samples // African Invertebrates. Vol.48. No.1. P.229-245.

Townes H.K. 1970. The genera of Ichneumonidae, Part 3 // Memoirs of the American Entomological Institute. Vol.13. No.1969. P.1-307.

Townes H.K., Townes M. 1978. Ichneumon-flies of America north of Mexico: 7. Subfamily Banchinae, tribes Lissonotini and Banchini // Memoirs of the American Entomological Institute. Vol.26. P.1-614.

Yu D.S., van Achterberg K., Horstmann K. 2005. World Ichneumonoidea 2004. Taxonomy, Biology, Morphology and Distribution. CD/DVD. Vancouver: Taxapad. http://www.taxapad. com 